\title{
Prevalence of Intestinal Parasites among Patients Attending Zella Central Laboratory, Zella City, Libya
}

\section{Khdija Suleman Mohamed Ali}

Department of Biology, Faculty of Science, Aljufra University, Libya

\section{Keywords:}

E. histolytica

G. lamblia

Intestinal parasites

A. lumbricoides

Zella

Libya

\begin{abstract}
A B S T R A C T
Intestinal parasites have become one of the most important health problems for public health experts and decision-makers in many countries. In Zella city, the prevalence of intestinal parasites was not studied before, therefore, the current study was conducted to identify the intestinal parasites in Zella city. The data in this study was collected from the records of the central laboratory in Zella city over the period of time, from the beginning of 2015, till the end of 2019. A 839 samples were examined, and 728 samples were infected with parasites, which represent $87 \%$. The results of the study revealed the presence of four types of intestinal parasites with different proportions as follows: Entamoeba histolytica by $65 \%$, Ascaris lumbricoides by $24 \%$, and Entamoeba coli by $10 \%$, and Giardia lamblia by $0.7 \%$. The results of the study also indicate that the infection rate of males and females were very close, $86 \%$ and $87 \%$, respectively. The results of the current study also indicate that the single type infection pattern was the most common compared to the mixed parasite infection, $95 \%$, and $5 \%$, respectively. The study also shows that the percentage of intestinal parasites infection was higher during the autumn and spring seasons. Despite the increase in cultural and social awareness and the improvement of the living conditions of many families, the rate of intestinal parasites infection is still high, which requires more investigations.
\end{abstract}

إنتشـار الطفيليات المعوبة بين المرضى المترددين على مختبرزلة المركزي. مدينة زلة / ليبيا

قسم علم الحيوان، كلية العلوم، جامعة الجفرة، ليبيا

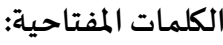

الطفيليات المعوية

ليبيا

زj

E. histolytica G. lamblia

A. lumbricoides

*Corresponding author:

E-mail addresses: Khdija.ali@ju.edu.ly

Article History : Received 06 March 2021 - Received in revised form 03 July 2021 - Accepted 08 July 2021

اصبحت الطفيليات المعوية من أهم المشاكل الصحية لدى خبراء الصحة العامة وصناع القرار في جميع الدول، نظرا لانتشارها الواسع في مناطق مختلفة وبيئات متعددة، مسببة العديد من المشاكل الصحية التي تؤثر بشكل حئل

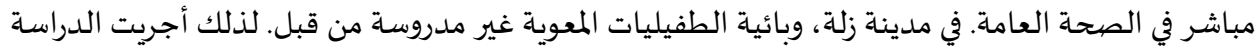

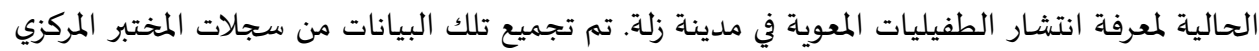
بالمدينة خلال الفترة من بداية سنة 2015م إلى نهاية سنة 2019م. خلال فترة الدراسة تم فحص ملد 839 عينة ،

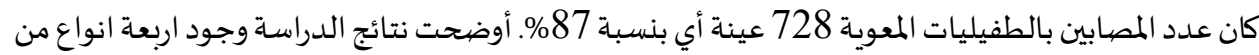

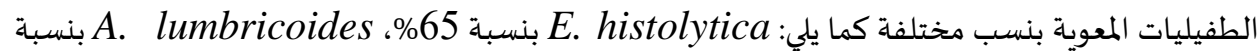

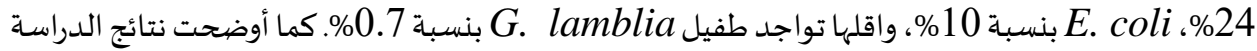
أن نسبة إصابة الذكور والإناث كانت متقاربة جدا وكانت بنسبة 86\% و 87\% على التوالي. كما أوضحت نتائج الدراسية الحالية بأن نمط الإصابة بالطراز المفرد كان هو الاكثر شيوعا مقارنة بنمط الإصابة بالطراز المزدوج وهابة

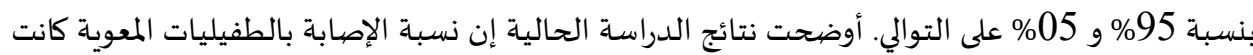
أعلى خلال فصلي الخريف والربيع بنسبة 27\% و 26\% على التوالي، مقارنة بنسبة انتشار الطفيليات المعوية خلال فصلي الشتاء والصيف، بنسبة 24\% و23\% علي التوالي. على الرغم من زيادة الوعي الثقافي والاجتماعي 


\section{Introduction}

Intestinal parasites are one of the most important pathogens spread globally, especially in tropical and subtropical regions, as the number of infected people with Protozoa or Helminthes is estimated annually about 3.5 billion people, most of them children [1]. Parasites live in the gastrointestinal tract, especially the large intestine and small intestine of hosts in different age groups, causing many pathological symptoms such as diarrhea, weight loss and loss of appetite. The diarrhea is one of the main causes of death in children, especially in some countries that lack the necessary conditions for personal hygiene and health care [2] Environmental, social, cultural conditions, and the level of family income in different societies are among the most important factors associated with the spread of intestinal parasites infection. Due to the overlap of clinical symptoms of parasite infection with the clinical symptoms of other causes of diarrhea such as bacteria and viruses, the mechanism of pathogen induced by intestinal parasites infection has not been sufficiently studied. Children are more likely to be infected with intestinal parasites, a study conducted by Kassem et al [3] in Sirte showed that the social and economic status of parents was related to the prevalence of intestinal parasites. Most of the diarrhea cases in developing countries, is related to intestinal parasites, in particular with in communities in rural areas, where poor health conditions, and the use of untreated sewage water in irrigation operations, [4].

Based on the results of many studies, the percentage of intestinal parasites infection varies from place to another depends on the location. In Saudi Arabia it was 27.8\%, [5], in Yemen 53\% [6], in Iraq 64.16\% [7], in Pakistan 52\% [8] and in Ethiopia 16.6\% [9]. Inside Libya also, the rates of intestinal parasite infection varied between different regions, in Zawiya it was $10.6 \%$, [10], Al Khums $15.4 \%$ [11], in Derna was 31\%, [12] and in Huon was $12.7 \%$ [13]. It is noticeable that there is a variation in the percentage of infection with different parasitic species from one place to another. A study carried out by [14] in Mosul, Iraq on the causes of bloody diarrhea in children under five years of age, indicated that, the infection with $E$. histolytica were the highest $84 \%$.

Previous studies showed a variety of intestinal parasites that infect individuals according to the study area. The study by Alsuqi and Daw [15] showed the presence of four parasitic types that were widespread among the cases that were reported in Tripoli Central Hospital with different rates as follows: G. lamblia by $42.36 \%$,

histolytica by $34.7 \%$, and $E$. coli by $22.9 \%$. The results of another study conducted by [16] on the spread of intestinal parasites in the Zintan region showed that the rate of infection with intestinal parasites was $59.86 \%$, and the most common was Entrobius vermicularis by $48.9 \%$, then infection with $E$. histolytica by $48.9 \%$. $24.48 \%$, and the lowest percentage was due to infection with $G$. lamblia parasite $2.04 \%$. Due to their medical and social importance, intestinal parasites around the world became interest to many researchers and decision-makers [17]. So, the current study was aims to identify the types of intestinal parasites, and infection rates during period of five years, in the Zella city, which located in the municipality of Al-Jufra, and obtained results will help of drawing a geographic map of distribution intestinal parasite in different regions.

\section{Materials and Methods}

Data of this study were collected from the records of Zella Central Laboratory, the city is located $750 \mathrm{~km}$ to the southeast of the Libyan capital, Tripoli, on the coordinates of ${ }^{\circ} 32^{\prime} 56^{\prime \prime} \mathrm{N} 17^{\circ} 33^{\prime} 04$ " $\mathrm{E}$, and the city is located in the administrative boundary of the municipality of Al-Jafra, as it connects it to the city of Wadan by a paved road with a length of $164 \mathrm{~km}$, while it is linked to the city of Marada by a paved road of $225 \mathrm{~km}$. The population of Zella is 13,000 people (Development Planning Guide for the Al-Jafra Municipality for the year 2018), in addition to large number of refugee settlers inside the city. Data of this study were collected from the records of Zella Central Laboratory over the period of time, from the beginning of 2015, to the end of 2019. The samples were examined using direct wet mount preparation by using normal saline and iodine stain. According to the Data of Zella Central Laboratory, the following were counted: the total number of patients, the date of the analysis, patient sex, and the type of parasite infection.

Statistical analysis. In this study descriptive statistical approach (All the collected date were used), and results were presented as percentages.

\section{Results \\ 1) Prevalence of intestinal parasitic infections during the study period.}

The results obtained (Table 1) indicated that the total number of tested subjects was 839 patients, there were 728 of them infected with intestinal parasite (87\%). The results of the current study also indicated that the percentage of infection varied in the study period. Where the highest rate of infection was during 2018, when the number of tested samples reached 150 patients, and 139 were infected (93\%). Followed by the infection rate in 2015 , which amounted to $90 \%$, as the total number of tested samples were 178 , of whom 161 were infected. Then the infection rate in the year 2017, which was $86 \%$, as the number of tested reached 157 patients, the number of infected patients was 135 cases, but in the year 2019, the number of tested reached 232 people, and the number with the parasites were 197 cases, or $85 \%$. While the lowest infection rate was $79 \%$, during 2016, when the number of tested samples were 122 patient, and 96 patients were infected with the intestinal parasite.

Table 1: prevalence of intestinal parasitic infections.

\begin{tabular}{cccc}
\hline Year & $\begin{array}{c}\text { N. of tested } \\
\text { samples }\end{array}$ & $\begin{array}{c}\text { N. of infected } \\
\text { samples }\end{array}$ & Percentage (\%) \\
\hline 2015 & 178 & 161 & $90 \%$ \\
2016 & 122 & 96 & $79 \%$ \\
2017 & 157 & 135 & $86 \%$ \\
2018 & 150 & 139 & $93 \%$ \\
2019 & 232 & 197 & $85 \%$ \\
Total & 839 & 728 & $87 \%$ \\
\hline
\end{tabular}

\section{2) Type of intestinal parasites infection}

Table (2) shows the types of intestinal parasites infection, their number and percentage of infection. The results obtained indicated that the single infection pattern was the most common type in Zella city, with percentage of $95 \%$. It was also found that the percentage of single infection with $E$. histolytica the highest $65 \%$, followed by the percentage of single infection with A. lumbricoides, and then the single infection with E. coli, with percentages of $24 \%$ and $10 \%$, respectively. The lowest percentage of single infections only was $0.7 \%$ due to infection with $G$. lamblia parasite. The results obtained also showed that the mixed parasite infection was a low incidence, as it appeared in 39 cases out of the total number of 728 cases, with a rate of $5 \%$ of the total infection. The parasite presence was $E$. histolytica $+A$. lumbricoides are the highest among mixed parasite infection, with a rate of $64 \%$. While the prevalence of $E$. coli $+A$. lumbricoides was $21 \%$. The lowest mixed parasite infection it was formed by the presence of $E$. histolytica $+E$. coli together with an infection rate of $15 \%$. 
Table 2: Type of intestinal parasites infection

\begin{tabular}{|c|c|c|c|c|c|}
\hline $\begin{array}{l}\text { Type of } \\
\text { infection }\end{array}$ & $\mathrm{N}$. & $\%$ & Parasite species & $\mathrm{N}$. & $\%$ \\
\hline \multirow{4}{*}{$\begin{array}{c}\text { Single } \\
\text { parasite } \\
\text { infection }\end{array}$} & \multirow{4}{*}{689} & \multirow{4}{*}{$95 \%$} & E. histolytica & 488 & $65 \%$ \\
\hline & & & E. coli & 71 & $10 \%$ \\
\hline & & & G. lamblia & 05 & $0.7 \%$ \\
\hline & & & A. lumbricoides & 165 & $24 \%$ \\
\hline \multirow{3}{*}{$\begin{array}{c}\text { Mixed } \\
\text { parasite } \\
\text { infection }\end{array}$} & \multirow{3}{*}{39} & \multirow{3}{*}{$05 \%$} & $\begin{array}{l}\text { E. histolytica }+ \\
\text { A.lumbricoides }\end{array}$ & 25 & $64 \%$ \\
\hline & & & $\begin{array}{c}\text { E. coli }+ \\
\text { A.lumbricoides }\end{array}$ & 08 & $21 \%$ \\
\hline & & & $\begin{array}{c}\text { E. histolytica }+ \\
\text { E. coli }\end{array}$ & 06 & $15 \%$ \\
\hline
\end{tabular}

\section{3) Single and mixed parasitic infection}

The results of the current study (Table 3) showed that citizens in Zella were infected with four types of intestinal parasites, three of which belong to the parasitic protozoans: E. histolytica, E. coli, and G. lamblia, and the fourth type was due to the intestinal worms
A. lumbricoides. The E. histolytica was the most common parasite among the parasitic protozoa. The number of people infected with this parasite reached 448 , with an infection rate of $65 \%$. The results of the study also indicated that the highest rate of infection was in $2015(71 \%)$, and the lowest rate of infection with the histolytica was in $2016(57 \%)$. While the number of people infected with $E$. coli reached 71 patient, and the percentage of infection did not exceed $10 \%$, and the results showed that the highest infection rate was in 2015 (14\%), while the lowest infection rate was in $2016(06 \%)$ While the percentage of $G$. lamblia was few and did not exceed 5 cases, with a percentage of only $0.7 \%$. It is worth noting that $G$. lamblia infection were limited to the years 2018, with three cases, and in 2019 with only two cases. As for the infection with parasitic worms, it was represented by one type of worms, A. lumbricoides, where the number of infected people reached 165 , with a percentage of $24 \%$. The highest rate of A. lumbricoides infection was in 2016 (37\%), while the lowest rate was in 2015 (14\%).

Table 3: Single and mixed parasitic infection

\begin{tabular}{|c|c|c|c|c|c|c|c|c|c|}
\hline \multirow{3}{*}{ Year } & \multicolumn{6}{|c|}{ parasitic protozoans } & \multirow{2}{*}{\multicolumn{2}{|c|}{$\begin{array}{l}\text { intestinal worms } \\
\text { A lumbricoides }\end{array}$}} & \multirow{3}{*}{ Total } \\
\hline & \multicolumn{2}{|c|}{ E. histolytica } & \multicolumn{2}{|c|}{ E. coli } & \multicolumn{2}{|c|}{ G. lamblia } & & & \\
\hline & N. & $\%$ & $\mathrm{~N}$. & $\%$ & N. & $\%$ & N. & $\%$ & \\
\hline 2015 & 114 & $71 \%$ & 23 & $14 \%$ & 0 & 0 & 23 & $14 \%$ & 160 \\
\hline 2016 & 54 & $57 \%$ & 6 & $6.0 \%$ & 0 & 0 & 35 & $37 \%$ & 95 \\
\hline 2017 & 78 & $61 \%$ & 15 & $12 \%$ & 0 & 0 & 35 & $27 \%$ & 129 \\
\hline 2018 & 80 & $62 \%$ & 9 & $10 \%$ & 3 & $2 \%$ & 38 & $29 \%$ & 130 \\
\hline 2019 & 121 & $70 \%$ & 18 & $10 \%$ & 2 & $1 \%$ & 34 & $19 \%$ & 175 \\
\hline Total & 448 & $65 \%$ & 71 & $10 \%$ & 5 & $0.7 \%$ & 165 & $24 \%$ & 689 \\
\hline
\end{tabular}

\section{4- Prevalence of intestinal parasite infections according to the} gender.

Table (04) shows the percentage of intestinal parasites infection according to the gender. The results of the study showed that the number of males examined was 432 males, and the number of infected males was 374 patients $(86 \%)$. While the number of examined females was 407 , there were 354 of them infected (87\%) with intestinal parasite.

Table 4: Type of intestinal parasites infections according to the gender

\begin{tabular}{cccc}
\hline Sex & $\begin{array}{c}\text { N. of tested } \\
\text { samples }\end{array}$ & $\begin{array}{c}\text { N. of infected } \\
\text { samples }\end{array}$ & $\begin{array}{c}\text { Percentage } \\
(\%)\end{array}$ \\
\hline male & 432 & 374 & $86 \%$ \\
Female & 407 & 354 & $87 \%$ \\
Total & 839 & 728 & $87 \%$ \\
\hline
\end{tabular}

5) Seasonal variation of intestinal parasitic infections.

Table (5) illustrated infection with intestinal parasites during the seasons of the year. The results of the study showed that infection with intestinal parasites in the city of Zella was close during the different seasons of the year.

However, the highest infection rate was $27 \%$ during the autumn, followed by $26 \%$ in the spring, and $24 \%$ in the winter. The results of the current study showed that the lowest rate of infection was $23 \%$ during the summer season.

Table 5: seasonal variation of intestinal parasitic infections

\begin{tabular}{lcccc}
\hline Year & Winter & Spring & Summer & autumn \\
\hline 2015 & 19 & 39 & 41 & 62 \\
2016 & 27 & 32 & 19 & 18 \\
2017 & 37 & 40 & 32 & 26 \\
2018 & 39 & 25 & 33 & 42 \\
2019 & 53 & 53 & 42 & 49 \\
Total & 175 & 189 & 167 & 197 \\
$(\%)$ & $24 \%$ & $26 \%$ & $23 \%$ & $27 \%$ \\
\hline
\end{tabular}

\section{Discussion}

Infection with intestinal parasites is becoming a big concern for public health in the developing as well as developed countries, due to their wide prevalence and the multiple health problems they cause.
Among the most important health problems caused by infection with pathogenic intestinal parasites such as E. histolytica and G. lamblia are gastrointestinal symptoms such as abdominal cramps, diarrhea, dyspepsia and anemia, [18]. Those symptoms lead to a direct effect on public health, body immunity and disease resistance, especially in children and families with limited income. Therefore, intestinal parasites have received international attention. Results of the current study showed that the rate of infection with intestinal parasites in general, during the years of the study was $87 \%$, and this percentage is high compared to a study conducted in Zintan [16], where the incidence of intestinal parasites was $59.85 \%$, while the rate of infection with intestinal parasites was $10.5 \%$ among the patients attending Sebha Central Hospital [19], while the rate of infection with intestinal parasites among school children in Wadi Shati was $23.82 \%$ [20], and in Tripoli was $15.7 \%$. [21]

The results of this study confirmed the results of the other studies, which reported that infection with one type of parasite (single parasite infection) was more common, compared to mixed parasite infection. $[10,19,22]$, the infection rate was $95 \%$ and $05 \%$, respectively. These results were similar to the results of Zaed [13], which showed that the rate of infection with the single type was $16.83 \%$, compared to the rate of infection with the mixed parasites of $6.33 \%$. Also in Sabha city mixed infection was only $0.2 \%$ compared to $99.7 \%$ for the single infection [18]. Other study curried out by Hasan, et. al. [23] reported that, there was only five causes of mixed parasite infection were founded out of 142 sample (3.5\%). It's worth mention that results of the current study showed that mixed infection of E. histolytica and A. lumbricoides was the most common (64\%). The results also showed that the incidence of parasitic protozoans was higher (76\%), compared to the rate of helminth infection $24 \%$. This result was in agreement with the results of a study conducted in Benghazi by Hasan and Morad [18], where the incidence of parasitic protozoa was $75.6 \%$. While the infection rate with parasitic worms was $24.4 \%$. The incidence of intestinal worms in the city of Zella in the current study was high may be due to different environmental conditions, living conditions and geographical location.

The results of the current study also showed that there are four main types of intestinal parasites that were common in the city of Zella, and the rates of infection varied according to their type. E. histolytica parasite was the most common by $65 \%$, followed by A. lumbricoides by $24 \%$, then $E$. coli, with $10 \%$, the least common parasite was $G$. 
lamblia, $0.7 \%$. However, the results of many studies showed that intestinal parasites and their prevalence rates varied in different regions. For example, the results of the study conducted in Huon, 180 $\mathrm{km}$ from Zella city, by Zaed [13], illustrated that the most common parasitic species were E. dispar, E. histolytica by $4.33 \%$, followed by E. coli by $2.83 \%$, then G. lamblia by $30.5 \%$, Endolimax nana $(2.83 \%)$, and Blastocystis hominis (1.83\%). Whereas, the common parasites in Sebha city suth of Libya, according to a study [18] were as follows: B. hominis by $6.8 \%$, E. histolytica, E. dispar by $2.3 \%$, G. lamblia by $0.9 \%$, and E. coli by $0.3 \%$. The main reason for the spread of intestinal parasites, especially E. histolytic parasite, may be due to the direct transmission methods of these parasites through the contaminated resources. Many Studies have shown that the incidence of amoebiasis infection differs in different areas of the study. The infection rate in Zella city was high, reaching $65 \%$. Wish was in agreement with the results of the study [24] in Nalut city west of Libya, where the incidence of infection with amoebiasis was $21 \%$ [25], in Huon was 4.3\% [13], in Sabha it was 2.3\% [18], and in Zintan it was $12.76 \%$ [17]. However, Esalem, et. al, [26] reported that the infection rate of E. histolytica dese not exceed $4 \%$ among children in Sabha city. It is worth mention that the results of the current study showed that the prevalence of the non-pathogenic E. coli parasite was $10 \%$, which is considered a high percentage compared to the results of other studies such as the study of [12] which showed that the infection rate was $3.2 \%$ in Derna city in the east, and in Zawia city west of Tripoli was 3.6\% [10]. G. lamblia parasite is one of the most common parasitic protozoa that cause diarrhea in tropical and subtropical regions, specifically in areas that suffer from lack of safe drinking water sources.

The prevalence of G. lamblia in the current study was low compared to the other parasitic species in Zella city, and it did not exceed $0.7 \%$. This result of this study was like the results of other studies. In Zintan was $1.2 \%$ [27], in Tripoli was $1.3 \%$ [28]. It is noticeable that the prevalence of G. lamblia was higher in some cities of the eastern region, where the infection rate was $11.4 \%$ in Benghazi [24], and in the city of Derna it was 12.7. \% [15].

Intestinal worms' infection is widespread worldwide, and is considered one of the most important health, economic and social problems around the world [1]. However, results of this study showed that the infection with A. lumbricoides was $24 \%$. No studies have been conducted before regarding the causes of the spread of intestinal worms in the region, while some studies indicated that the cause of their spread is due to lack of good ventilation and moist soil, and the eggs of the worms have the ability to be transmitted by rodents scattered in the affected areas. However, in Huon the results of [13] did not record any presence of $A$. lumbricoides. Also, the study of El-Araby and others did not record infection with A. lumbricoides in Zintan. [16]. Results of the current study indicated that the percentage of male and female infected with intestinal parasite was very close. The results of this study were consistent with some previous studies, as the results of the study [18] showed that the rate of infection of males and females with intestinal parasites in Sabha was $10.9 \%$ and $10.2 \%$ for males and females, respectively. As well as the results of the study of [13], which showed that the male infection rate was higher than that of the female, but the differences were not significant, and also Okyay, et. al [29], Akinbo et. al. [30] reported there were no significant different between the infection of the male and female with intestinal parasite.

The results of the present study showed that the highest prevalence of intestinal parasites was during the autumn and spring seasons (27\% and 26\%) respectively. The lowest was during the summer, $23 \%$. The results of the current study were in agreement with the results of) [18], which showed that the highest prevalence of intestinal parasites in Sebha was during the autumn and winter seasons by $16.6 \%$ and $13.4 \%$, then the rate of infection during the spring and summer season by $9.8 \%$ and $7.3 \%$, respectively. This was explained by the fact that the high temperature and low humidity led to a decrease in the incidence of intestinal parasites infection.

\section{Conclusion}

Results of the current study illustrated that, there were high percentage of infection with intestinal parasite in Zella city. $E$. histolytica was the most important parasite with infection rate of $65 \%$, followed by A. lumbricoides $24 \%$. the result of also revealed that infection with single parasite was more common compared to infection with mix parasite infection, and the rate of infection of male and female was very closed. Interestingly the result illustrated that, the highest infection rate was during autumn season. From the results of the current study, attention should be paid to increase the public awareness, and intestinal parasite transition. Furthermore, a comprehensive epidemiological studies are needed to guide decision makers in the relevant sectors to control intestinal parasites.

\section{Acknowledgment}

I would like to thank Dr. Hana Moftah Mukhtar, the director of Nastaen Clinic for medical services, and the Laboratory technician, Mis, Salha Mohammed Moftah, for there assistance in collecting the date of this study.

\section{References}

[1]- Haque R. (2007). Human intestinal parasites. Journal of health, population, and nutrition, 25(4): 387-391

[2]- Alum, A., Rubino, R. and Ijaz, K. (2010). The global war against intestinal parasites should we use a holistic approach. International journal of infectious diseases, 14(9): $732-728$.

[3]- Kasssem, H., Zaed, A. and Sadaga, A. (2007). Intestinal parasitic infection among children and neonatus admitted to Ibn-Sina Hospital, Sirt, Libya. Journal of the Egyptian Society of Parasitology, 37(2): 371-380

[4]- Cacciò, M., De Giacomo, M., Aulicino, A. and Pozio, E. (2003). Giardia cysts in wastewater treatment plants in Italy. Applied and environmental microbiology, 69(6): 3393-3398.

[5]- Akhter, J., Burdette, M., Qadri, M., and Myint, H. (1994). Aetiology of gastroenteritis at a major referral centre in Saudi Arabia. The Journal of international medical research, 22(1): 47-54.

[6]- Farag, H. (1985). Intestinal parasitosis in the population of the Yemen Arab Republic. Tropical and geographical medicine, 37(1): 29-31

[7]- Zuhair, I., Fattouhi, S., Sharif, H. and Nagwa, M. (2008). A study on intestinal parasites that cause diarrhea and some influences on them in children in Nineveh Governorate. Al-Rafidain Science Journal, 19(2): 37-50.

[8]- Mehraj, V., Hatcher, J., Akhtar, S., Rafique, G. and Beg, M. A. (2008). Prevalence and factors associated with intestinal parasitic infection among children in an urban slum of Karachi. PloS one, 3(11): e3680. https://doi.org/10.1371/journal.pone.0003680.

[9]- Taye, S. and Abdulkerim, A. (2014). Prevalence of Intestinal Parasitic Infections among Patients with Diarrhea at Bereka Medical Center, Southeast Ethiopia: A Retrospective Study. Medical Science Research, 3(3): 2327-4972.

[10]- Elsaid, M., Shaktur, A., Elsaid S., Elalem, M., Traish, K. and Kahbar, F. (2014). Prevalence of intestinal protozoa in primary schools in Zawia City, Libya. Natural Science, 12(4): 67-71.

[11]- Elammari, N. and Nair, G. (2015). Critical evaluation of the intestinal Protozoan parasites among Libyan and other African residents of Al-Khoms, Libya. Journal of Entomology and Zoology Studies, 3(2): 42-46.

[12]- Sadaga, A. and Kassem, H. (2007). Prevalence of intestinal parasites among primary schoolchildren in Derna District, Libya. Journal of the Egyptian Society of Parasitology, 37(1): 205-214.

[13]- Zaed, A. (2018). A Study of the prevalence of human intestinal parasites in some primary school children in Houn city, Libya. Academic Research Journal, 11: 654-679.

[14]- Al-ani, A., Al-Mukhlis, J. and Edward, S. (2000). Epidemiology of bloody diarrhea. Iraqi Journal of community medicine, 13(1): 6-9.

[15]- Alsuqi, A. and Daw, M. (2013). The spread of some primary intestinal parasites in humans in the infected cases registered in the Tripoli Central Laboratory, Egypt. Acad. J. Biolog. Sci, 5(1): 21-29

[16]- Alarabi, A. and Jamea, M. (2019). A study of the extent of the spread of some intestinal parasites in the visitors of Zintan, 
Umm Al-Jarsan and Yefren hospitals in the Western Mountain region. Journal of the College of Education, 13: 276-289.

[17]- Fletcher, M., Stark, D., Harkness, J. and Ellis, J. (2012). Enteric protozoa in the developed world: a public health perspective. Clinical microbiology reviews, 25(3), 420-449.

[18]- Hasan, S. and Morad, S. (2019). Prevalence of intestinal protozoan parasitic infections among people attending Sebha Central Laboratory in Sebha, Libya: a retrospective study. International Journal of Applied Science, 1(1):374-385.

[19]- Saad, G., Khan, A., Ajaili, A., Abdulsalam, A., Alshebani, M. and Kubti Y. (2009). A study of prevalence of human intestinal parasites in Wadi Al-Shati region. Sebha Medical Journal, 8(2): 51-58.

[20]- Elboulaqi, A., Dar, K. and Medini, S. (1980). Prevalence intestinal parasites in primary school children in Benghazi city. Journal of the Egyptian Society of Parasitology, 10(1):77-82.

[21]- Gashout A, Taweni F, Elmabrouk H. (2017).Pattern of intestinal parasites among hospital patients at Tripoli Central Hospital, Libya. Libyan Journal of Medical Sciences, 1(1):13-15.

[22]- Al-Mohammed H. I., Amin T. T, Aboulmagd E., Hablus H. R., Zaza B. O. (2010): Prevalence of intestinal parasitic infections and its relationship with socio-demographics and hygienic habits among male primary schoolchildren in Al-Ahsa, Saudi Arabia. Asian Pacific Journal of Tropical Medicine. 3(11): 906912.

[23]- Hasan M. S. Ibrahim \& Abubaker H. A. Salem. (2020).Prevalence of Intestinal Parasitic Infections Among People in Sebha City, Libya. Journal of Pure \& Applied Sciences. 9(2): 6-12.

[24]- Dar, F., Elkhouly, S., El-boulaqi, H., Munir, R. and Eimaghrebi, S. (1979). Intestinal Parasites in Benghazi School Children. Garyounis Medical Journal, 2(1): 3-7.

[25]- Alkilani, M., Dahesh, S. and Taweel, H. (2008). Intestinal parasitosis in Nalout popularity. Western Libya Journal of the Egyptian Society of Parasitology, 38(1): 255-264.

[26]- ESalem R. M. A., Gahgah S. A. A., Ali A. S. H., Alsharif S. A. R. (2017). Prevalence and risk factors associated with Entamoeba Histolytica infection among children in Sebha, Libya. Dentistry and Medical Research. 5(2): 48-51.

[27]- Ali, B., Ghenghesh, S., Aissa, B., Abuhelfaia, A., and Dufani, M. (2005). Etiology of childhood diarrhea in Zliten, Libya. Saudi medical journal, 26(11), 1759-1765.

[28]- Rahouma, A., Klena, D., Krema, Z., Abobker, A., Treesh, K., Franka, E., Abusnena, O., Shaheen, I., Mohammady, H., Abudher, A. and Ghenghesh, S. (2011). Enteric pathogens associated with childhood diarrhea in Tripoli-Libya. The American journal of tropical medicine and hygiene, 84(6): 886891.

[29]- Okyay P.; Ertug S.; Gultekin B.; Onen O.; Beser E.(2004). Intestinal parasites prevalence and related factors in school children, a western city sample. Turkey, BioMed Central Public Health. 4(22): 4-64

[30]- Akinbo F., Omoregie R., Eromwon R., Igbenimah I., Airueghiomon U. (2011). Prevalence of intestinal parasites among patients of a tertiary hospital in Benin City, Nigeria. North American journal of medicine \& science. 3(10):462-464 